\title{
Afet Yönetimi ve Üniversite Kampüsü: 2011 Van Depremleri ve Van YYÜ Kampüsü Örneği
}

\author{
Güler ÖZYILDIRAN ${ }^{1,2}$ *
}

\section{Öz}

Geçmişte yaşanan afetlerde, yaşanan tecrübelerden çıkarılan dersler, afet yönetiminin günümüze kadar geliştirilmesine katkı sağlamıştır. Yakın tarihte Türkiye'de yaşanan en büyük afetlerden biri olan 2011 Van depremlerinde, kentin tek üniversitesi olan Van Yüzüncü Yıl Üniversitesi (Van YYÜ), depremden sonra kentte ilk toparlanan kurumlardan olmuş, şehir merkezinden $15 \mathrm{~km}$ uzakta bulunan kampüsünden, kentin afet yönetimine öncülük etmiştir. Afet yönetim sürecinin başında, dışarıdan desteğin kısıtlı olduğu ilk 72 saatte, Van YYÜ büyük ölçüde kendi imkanları ile çalışmalar yapmıştır. Sonrasındaki iyileşme ve yapılanma döneminde, diğer üniversiteler de araştırmaları ve faaliyetleriyle, Van depremi sonrası, kente katkı koymak istemiş ve bu desteklerini Van YYÜ odağında gerçekleştirmişlerdir. Bu tecrübe, bütün bir kentin faaliyetlerini kesintiye uğratan 2011 Van depremleri gibi büyük afetlerde, kentlerin afet yönetiminde, kendi üniversitelerinin ve kampüslerinin önemli bir rol alabileceğini göstermiştir. Bu araştırmada, 2011 Van depremleri sonrasında Van YYÜ kampüsünde yaşanan örnekler üzerinden, afet yönetiminde, bir üniversitenin, kendisi ve kenti için nasıl bir yol izleyebileceği incelenecektir. Araştırma, literatür taraması, Van depremleri raporları, söyleşiler, fotoğraflar ve yerinde gözlemlere dayanmaktadır.

Anahtar Kelimeler: Afet yönetimi, afet ve mimarlık, deprem, üniversite kampüsü, kampüs planlama, eğitim yapıları.

\section{Disaster Management and Universıty Campuses: Cases of 2011 Van Earthquakes and Van YYU Campus}

\section{Abstract}

The experience of the past disasters contributes to the development of the disaster management. In the recent history, one of the biggest earthquakes of Turkey occurred in Van in 2011. Van Yüzüncü Yıl University (Van YYU), the only university of the Van city, was one of the first recovered institutes after the 2011 Van earthquakes. Moreover, Van YYU pioneered the disaster management of the city in some aspects. As in the case of other disasters, the first 72 hours of the disaster was the beginning of the disaster management cycle, with limited external support. In this phase, Van YYU responded to the disaster within its capability. In the following phases (the rehabilitation and reconstruction phases), other universities also wanted to contribute to Van and they focused on Van YYU campus. This experience indicated that universities and their campuses may take significant roles in the

\footnotetext{
${ }^{1}$ Dr. Öğretim Üyesi, Van Yüzüncü Yıl Üniversitesi, Mimarlık ve Tasarım Fakültesi, Mimarlık Bölümü, Bina Bilgisi Anabilim Dalı, Van, Türkiye.

${ }^{2}$ Postdoktora Araştırmacısı, Orta Doğu Teknik Üniversitesi, Mimarlık Fakültesi, Mimarlık Bölümü, Bina Bilgisi Anabilim Dalı, Ankara, Türkiye.
}

* İlgili yazar / Corresponding author: gulerozyildiran@hotmail.com Gönderim Tarihi / Received Date: 02.05.2020

Kabul Tarihi / Accepted Date: 04.06.2020 
disaster management of their cities. This research examines the case of 2011 Van earthquakes in order to understand how a university and its campus can act in the disaster management of a city. The research based on literature survey, Van earthquake reports, interviews, photographs and site observations.

Keywords: Disaster management, disaster and architecture, earthquake, university campus, campus planning, education buildings.

\section{GIRIŞ: AFET YÖNETIMINE GENEL BAKIŞ}

Afetler, en yaygın tanımıyla, "toplumun tamamı veya belli kesimleri için fiziksel, ekonomik ve sosyal kayıplar doğuran, normal hayatı ve insan faaliyetlerini durduran veya kesintiye uğratan, etkilenen toplumun baş etme kapasitesinin yeterli olmadığı doğa, teknoloji veya insan kaynaklı olaylardır" (AFAD, 2014-a). Afet yönetimi, "afetlerin önlenmesi ve zararlarının azaltıması, afet sonucunu doğuran olaylara zamanında, hızlı ve etkili olarak müdahale edilmesi ve afetten etkilenen topluluklar için daha güvenli ve gelişmiş yeni bir yaşam çevresi oluşturulabilmesi için toplumca yapılması gereken topyekun bir mücadele sürecidir" (AFAD, 2014-a). Afetlerin tekrarlanma özelliği nedeniyle, bu süreç "afet yönetim döngüsü" olarak da ifade edilmektedir. Afet yönetim döngüsü, afetin hemen sonrasındaki müdahale çalışmaları ile başlar, sonrasında ise yeniden benzer bir afetin yaşanma intimaline karşılık, bir sonraki afet öncesinde risk azaltma çalışmaları ile devam eder. Afetin tekrar yaşanmasından sonra bu döngü tekrarlanır ama her seferinde daha tecrübeli, daha hazırlıklı ve riskleri en aza indirmiş olarak yaşanması hedeflenir (Şekil 1).

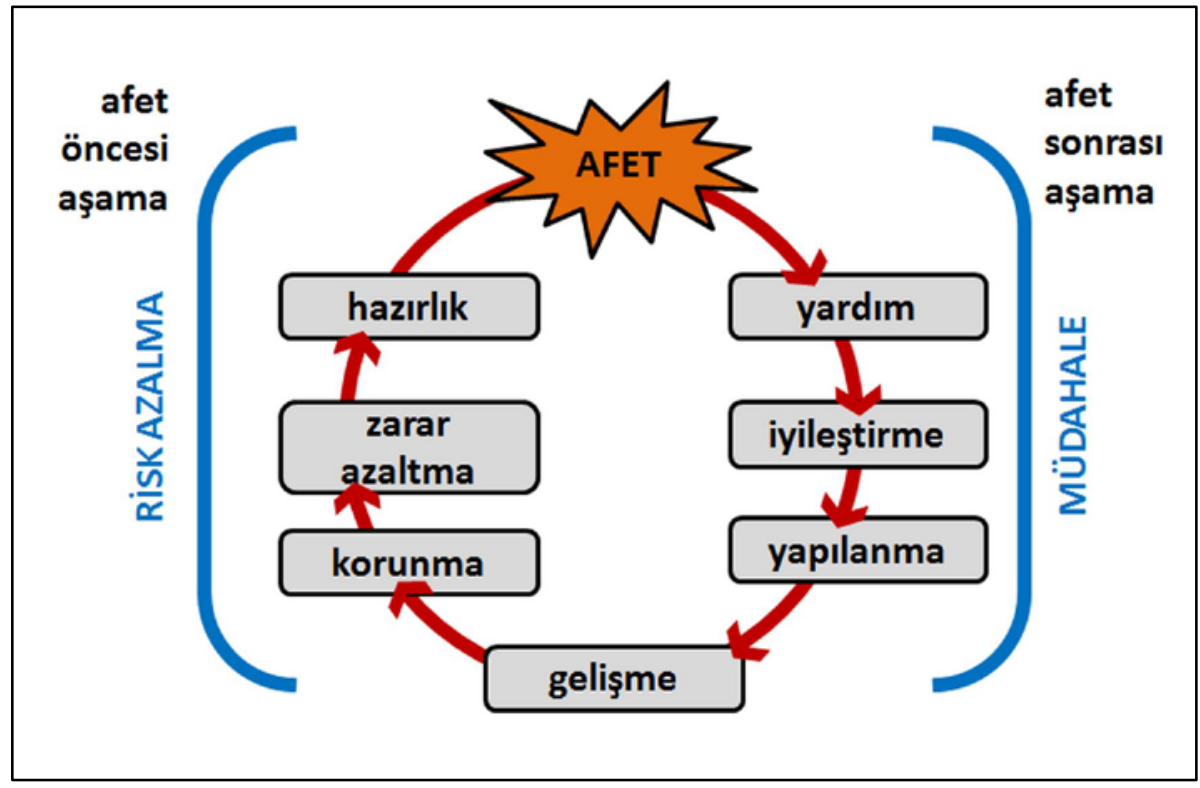

Şekil 1. Afet Yönetim Süreci (Afet Yönetim Döngüsü).

(kaynak: JICA (2004) s.47'den alınarak, yazar tarafından yeniden çizilmiştir).

\section{VAN KENTININ AFET PROFILI}

Türkiye'de yaşanan doğal afetler, yıkılan konut sayısı üzerinden incelediğinde, en çok hasar veren türlerin, başta depremler (\%76), sonra heyelanlar $(\% 10)$ ve su baskınları $(\% 9)$, en sonda da kaya düşmeleri (\%4) ve çığ düşmeleri (\%1) olduğu ortaya çıkmaktadır (Ergünay, 2007). Türkiye topraklarının \%92'si deprem bölgesi içinde yer almaktadır ve nüfusun ise yaklaşık \%95'i deprem tehlikesi altındadır (AFAD, 2014-b). 
Türkiye Cumhuriyeti tarihindeki en büyük depremlere baktığımızda, Van ilinin depremselliği ile ilgili ilginç sonuçlar görülmektedir. Bu depremler Ms değerine göre sıralandığında, en şiddetli 10 depremden iki tanesi Van'da meydana gelen, 1976 Van Muradiye (Ms=7.5) ve 2011 Van (Ms=7.2) depremleridir (Boğaziçi Üniversitesi KRDAE, 2020). Şekil 2'deki haritalar incelendiğinde ise, Van il sınırları içinde, heyelan, su baskını, kaya düşmesi ve çığ düşmesi afetleri için de riskli bölgeler olduğu görülmektedir. Dolayısıyla, Van Türkiye'nin en önemli deprem bölgelerinden biridir ancak afet yönetimi için sadece deprem konusunda değil, risk taşıdığı diğer afet türleri için de hazırıklı olması gerekir.

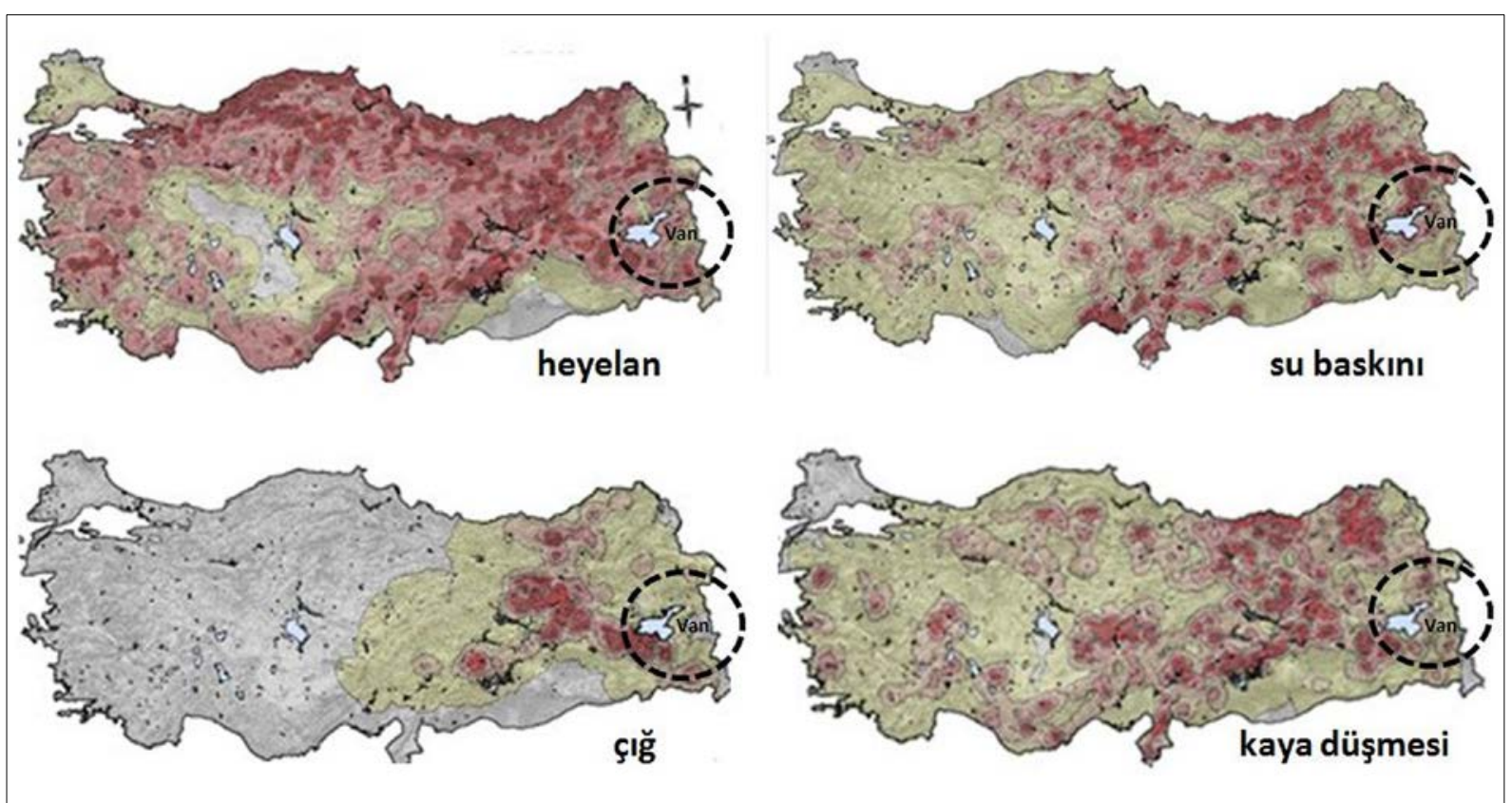

Şekil 2. Türkiye'nin afet profili haritaları ve Van'ın konumu.

(kaynak: AFAD, https://www.afad.gov.tr/kurumlar/afad.gov.tr/3500/xfiles/69-2014050710555turkiye nin-afetselligi.pdf adresindeki afet haritaları üzerine yazar tarafından işaretlenmiştir).

\section{VAN YYÜ KAMPÜSÜ VE 2011 VAN DEPREMLERI}

Van YYÜ kuruluş çalışmaları cumhuriyetin ilk yıllarında başlamış, kuruluşu 1982 yılında tamamlanmıştır. Kampüs yer seçim kararlarında ve kampüs planlamasında, 1976 Van Muradiye depremi tecrübesinin de etkili olduğu tahmin edilmektedir. Sezer (2008), kampüs yer seçimi için başlangıçta Van Edremit ilçesi civarında iki alan düşünüldüğünü, bu alanların fiziki ve jeolojik özelliklerinin, inşaat yapımına uygun olup olmadığının tespiti için bir heyetin 1979 yılında inceleme için çağırıldığını belirtmektedir. İlgili heyetin, inceleme sonrasında her iki alanı da yerleşim için olumsuz bulduğu, onlar yerine, kampüsün günümüzdeki yeri olan Bardakçı Köyü arazisini, her yönü ile yerleşim alanı için uygun bularak önerdiği ve böylece kampüs alanının kararlaştırıldığı aktarılmaktadır (Sezer, 2008).

1976 Van Muradiye depreminden sonra, Van'da en büyük depremler 2011 yılında yaşanmıştır. İlk deprem, 23 Ekim 2011 tarihinde meydana gelmiştir. Depremin merkezi, VanErciş yolu üzerinde, Van Merkez'in yaklaşık $30 \mathrm{~km}$ kuzeyinde, Tabanlı Köyü'dür(Şekil 3). Bu deprem, bazı kaynaklarda 2011 Van-Erciş depremi olarak bahsedilse de, resmi literatürde 2011 Van-Merkez depremi olarak isimlendirilmektedir (AFAD, 2014-b). Depremin üzerinden 17 gün geçtikten sonra, ikinci bir deprem de 9 Kasım 2011 tarihinde meydana gelmiştir. İkinci depremin merkezi Van'ın güney batısında, merkeze $16 \mathrm{~km}$ uzaklıktaki Edremit ilçesidir, 
deprem 2011 Van-Edremit depremi olarak isimlendirilmektedir (AFAD, 2014-b). Van-Merkez depremi (Ms=7.2) VIII şiddetinde yaşanmış ve 644 can kaybı olmuştur; Van-Edremit depremi (Ms=5.6) VI şiddetinde deprem olarak kayıtlara geçmiş ve 40 kişi hayatını kaybetmiştir (Boğaziçi Üniversitesi KRDAE, 2020).

AFAD (2014-b) kayıtlarında, 2011 Van depremlerinden sonra, yaklaşık 187 bin yapı incelendiği ve bu yapılardan yaklaşık 49 bin yapının yıkık veya ağır hasarlı olduğunun tespit edildiği belirtilmektedir. İncelenen konutların \%76'sının, işyerlerinin \%79'unun ve ahırların \%82'sinin hasarlı olduğu ve hasarsızlık oranının \%23 olduğu aktarılmaktadır (AFAD, 2014-b). Hasarlı bina sayısı için iki depremi ayrı ayrı ele alan verilere ulaşılamamıştır. Bunun nedeninin, 17 gün kadar kısa arayla meydana gelen iki büyük depremde, hasarlı bina tespitlerinin sonra yapılabilmesi ve yapı hasarlarında iki depremin birlikte tetikleyici olması düşünülebilir (Ayrıca, bahsi geçen iki depremin arasında ve sonrasında çok sayıda artçı depremler de yaşanmıştır). Depremi yaşayanlar, ilk depremde hasar alan bazı binalarda bu hasarların tam olarak fark edilemediğini, bu nedenle daha az şiddetli olmasına rağmen yaşanan ikinci depremin daha yıkıcı deprem olduğunu aktarmaktadır. İlk deprem sonrasında sağlam görünen, otel yapıları gibi bazı yapıların, ikinci depremde yıkılması, ilk deprem sonrasında kente araştırma yapmak, haber yapmak ve yardım etmek için dışarıdan gelenlerin bir kısmını da afetzede yapmıştır. Bu noktada, afet yönetiminde kullanılabilecek yapı gruplarının, afet sonrasında da dayanıklı olacak şekilde tasarlanması ve uygulanması önem taşımaktadır (Özyıldıran \& İmamoğlu, 2010).

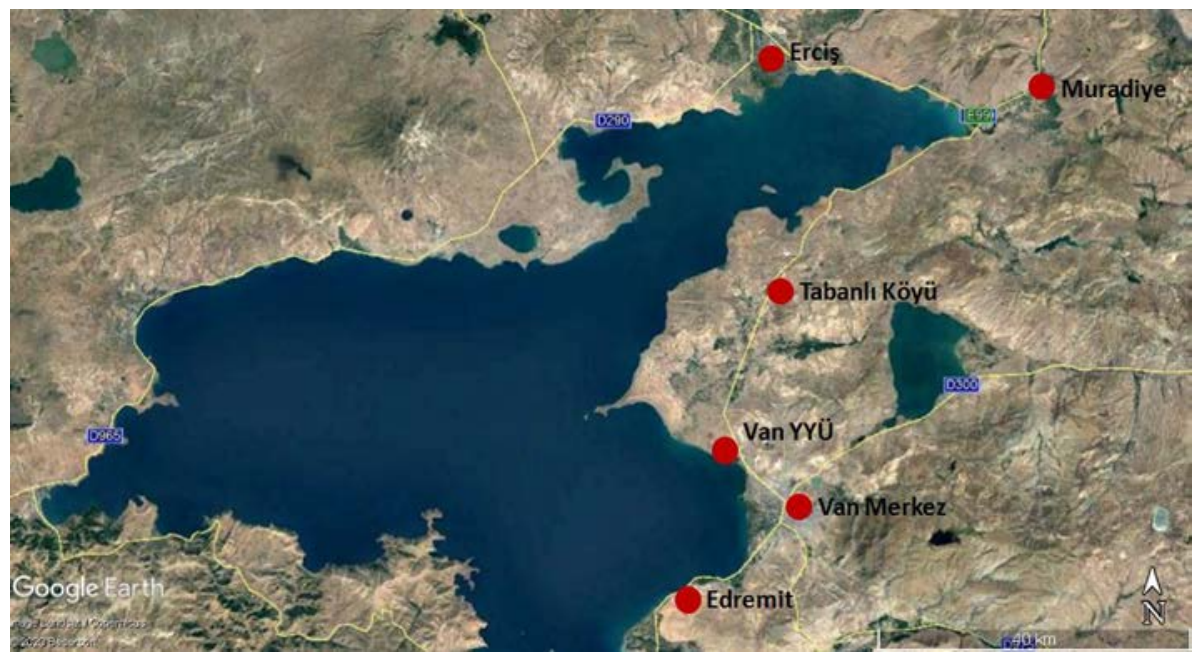

Şekil 3.Van kent merkezi ve yakın çevresi.

(kaynak: Googleearth uydu görüntüsü üzerine yazar tarafından işaretlenmiştir, 27.04.2020).

\subsection{Depremin İlk 72 Saatinde Üniversite}

Daha önceki depremlerde olduğu gibi, 2011 depremleri de beklenmedik bir zamanda, beklenmedik bir şekilde meydana gelmiştir. Afet literatüründe "altın saatler" olarak adlandırılan, ilk 72 saat, "bireylerin ve yerel halkın afet sonrasında yetkililer ve ekipler gelene kadar ilk üç gün kendi başına yeterli kapasiteye sahip olması istenen ve planlanan zaman dilimi" olarak tanımlanmaktadır (AFAD, 2014-a). Afet yönetim döngüsünün bu ilk aşamasında, "yardım aşaması", başka bir ifade ile "müdahale aşaması" yer alır. Kadıoğlu (2008), müdahale aşamasının, afetin büyüklüğüne göre üç gün ile bir iki aylık süreyi kapsadığını vurgulayarak, bu aşamadaki faaliyetlerin ana hedefinin, mümkün olan en kısa süre içerisinde çok sayıdaki insan hayatını kurtarmak, yaralıların tedavisini sağlamak ve açıkta kalanların su, yiyecek, giyecek, ısınma, barınma, koruma gibi hayati ihtiyaçlarını en hızlı ve en uygun yöntemlerle karşılamak olarak tanımlamaktadır. 
Van YYÜ kampüsü konum olarak, 23 Ekim 2011 ve 9 Kasım 2011 deprem merkezlerinin ortasında yer almaktadır. Kampüsün kuzeyinde Erciş ilçesinde, güneyinde Van Merkez ve Edremit ilçesinde çok sayıda yapının yıkıldığı ve can kayıpları yaşandığı bilinmektedir. Her iki deprem merkezinin arasında olmasına rağmen, kampüste deprem anında yıkılan bir yapı olmadığı ve can kaybı yaşanmadığı anlatılmaktadır. Ancak kampüsteki bazı yapıların ağır hasar aldığı ve artçı sarsıntılarla beraber kampüste bir panik ortamı oluştuğu bilinmektedir.

Üniversite yönetimi saat 13:40'ta meydana gelen ilk depremden sonra, önce kampüste, yurtlarında ve lojmanlarında herhangi bir yaralanma ve can kaybı olup olmadığını kontrol etmiş, sorun olmadığını öğrendikten sonra da öğrencilerin afet ortamından biran önce uzaklaşması için eğitime bir hafta ara verme kararı almıştır. Bu durumu, dönemin Rektörü Prof. Dr. Peyami Battal (2016), "Afet ile ilgili durumlarda, mümkünse afete maruz kalan insanların, normale döndüğü zaman, afet ortamını hemen görmemesi gerekiyor. Uzaklaşması en iyi çözüm. Yani afetin bulunduğu yerde çözüm bulmaktansa, uzakta bulunması gerektiğine inananlardanım" diye açıklamıştır.

Müdahale aşamasında önemli bir unsur da "haberleşme ve ulaşımdır" (Kadıoğlu, 2008). Bu süreci, Battal 2016 tarihli konuşmasında ayrıntılı olarak açıklamıştır. Öncelikle, üniversite yönetimi, Anadolu Ajansı üzerinden, kampüste problem olmadığını, öğrencilerin bir hafta izinli sayıldığını ve gitmek isteyen öğrencilerin ulaşımlarına üniversitenin yardımcı olacağını duyurmuştur. Böyle bir duyurunun, o sırada üniversitedeki yakınlarından haber alamayan, öğrenci velileri ve personel yakınları için rahatlama sağladığı ifade edilmiştir. Üniversitenin ana kampüs dışındaki, Erciş'teki öğrencilerinin ana kampüse getirildiği, il dışına gitmek isteyen öğrencilerin tahliyesi için otobüsler ayarlandığı ve gruplar halinde öğrencilerin gideceği illere sevk edildiği belirtilmiştir. Bu sırada, akşam olduğunda, kampüste dışarıda bekleyen öğrenci ve personelin ısınması için, Yurtkur'dan battaniye dağıtımı yapıldığı aktarılmıştır. Gece Van'a il dışından afet yardımı için kargo ve personel taşıyan uçakların gelmeye başlamasıyla, gelen bu uçaklar, gece 02:00 civarında üniversite yönetiminin talebi üzerine, otobüsle gönderilemeyen üniversite öğrencilerinin memleketlerine gönderilmesinde kullanılmıştır. Ertesi sabah 06:30 olduğunda ise, gitmek isteyip de gidemeyen tek bir üniversite öğrencisi kalmadığı, hatta gitmek isteyen personelin de gittiği ifade edilmiştir. O sabah 07:00'de kampüste dağıtılmak üzere çorbanın da hazır olduğu, ondan sonraki iki üç ay boyunca da, çevredeki depremzede olan herkese, üniversite yemekhanesinden yemek verildiği aktarılmıştır (Battal, 2016).

\section{2. Üniversitede Konteynerler Dönemi: Konteyner Derslikler, Konteyner Yurtlar, Konteyner Lojmanlar}

Afet yönetiminde, müdahale aşaması sonrasındaki aşama, "iyileşme" aşamasıdır. Bu aşamanın hedefi, afete uğramış toplulukların, uzun süreli geçici iskân, eğitim, ekonomik ve sosyal faaliyetler gibi hayati aktivitelerinin minimum düzeyde karşılanabilmesi için gereken çalışmaları yapmaktır (Kadıoğlu, 2008). Kadıoğlu (2008), bu aşamayı, "toplum ve bireylerin, işyerlerinin ve devlet kurumlarının kendi kendilerine çalışabilmeleri, normal yaşama dönmeleri ve gelecekte olası tehlikelere karşı korunmalarını sağlayacak şekilde yeniden yapılandırılması" şeklinde tanımlamıştır.

Van YYÜ'de bu aşamada, evlerine gönderilen öğrencilerin yeninden kampüse dönüp eğitimlerine devam edebilmeleri için, yaklaşık 2000 konteynerden oluşan, derslikler ve öğrenci yurtları hazırlanmıştır. Depremin üzerinden iki ay geçmeden, 26.12.2011 tarihinde, ilk etapta, Tıp Fakültesi ve Diş Hekimliği Fakültesi öğrencileri çağırılmış ve öğrenciler yeniden ders başı yapmıştır. Tıp Fakültesi 3., 4. ve 5. sınıf öğrencileri ise, hastane inşaatı tamamlanıncaya kadarki süre için, Türkiye'nin çeşitli üniversitelerine gönderilmiştir. Derslik 
olarak kullanılanlar dışındaki konteynerlerin bir kısmı, Yurtkur'a devredilerek, her biri dörder öğrencinin kalacağı şekilde yurda dönüştürülmüştür. İlk etapta, 84 konteyneri yurt olarak faaliyete geçirerek, 336 öğrencinin barınması sağlanmıştır. Konteynerlerin ısınmasının elektrikli ısıtıcılarla sağlandığı, ayrıca yurtların bulunduğu alanda çamaşırhane ve yemekhane alanları da oluşturularak, günde üç öğün ücretsiz yemek dağıtıldığı aktarılmıştır. Bu süreçte, akademik ve idari personelin barınması için de 500 konteynerin lojman olarak kullanıldığı, üniversite yönetiminin de konteynerlerde hizmet verdiği belirtilmektedir. Üniversitenin bu dönemi, basında da "konteyner üniversite" olarak duyurulmuştur. (Kızılkoyun \& Çağlar, 2012) (Şekil 4).
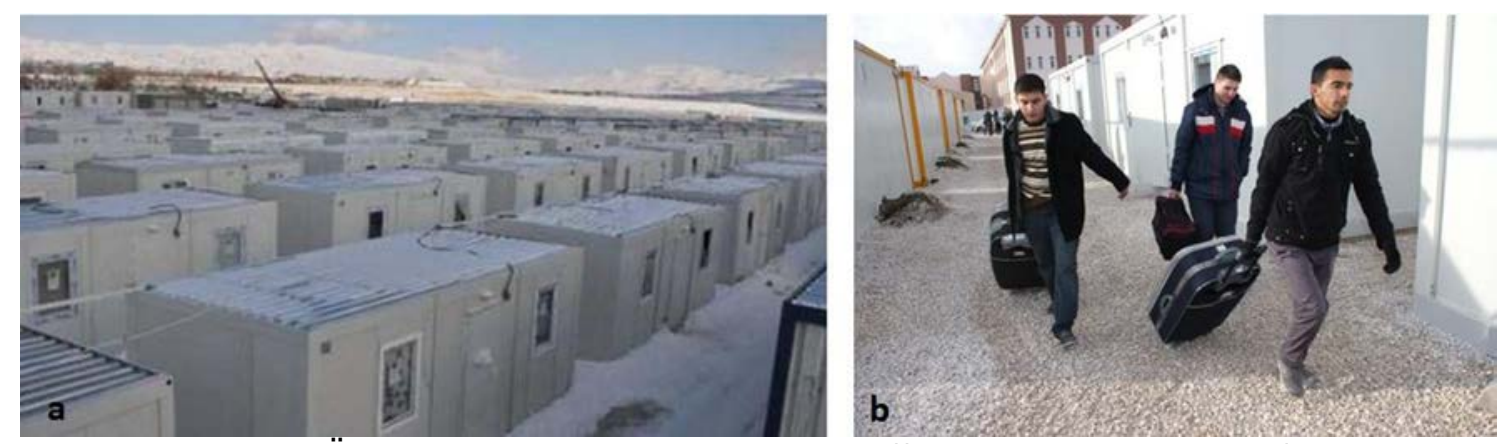

Şekil 4. a) Van YYÜ konteyner yurtlar (kaynak: http://haber.marmara.edu.tr/yyuye-2-binkonteyner-yerlestirildi/), b) Van YYÜ'de derslerin başlaması ile konteyner yurtlara yerleşmeye gelen öğrenciler (kaynak: http://www.haberler.com/yuzuncu-yil-universitesiyarin-ders-basi-yapiyor-3215622-haberi)

\section{3. Üniversitede Prefabrik Yapılar Dönemi: Prefabrik Derslikler, Prefabrik Yurtlar, Prefabrik Lojmanlar}

Üniversite, ilk etapta Aralık 2011 'de konteynerlerde iki fakültenin eğitimini başlatmışken, Mart 2012 'de tüm üniversite öğrencilerinin eğitimini başlatabilmek için çalışmaları genişletmiştir. Bu kapsamda, zarar gören binalar onarılıncaya ve artçı depremler hafifleyinceye kadar, öğrencilerin panik ve endişe olmadan ders yapabilecekleri, prefabrik derslikler için hazırlıklara başlanmıştır. Toplam 54 derslikli üç adet prefabrik blok, Van YYÜ imkanları ile yapılmış, toplam 17 derslikten oluşan iki adet derslik bloğu da, Çağdaş Yaşamı Destekleme Derneği ve ODTÜ Eymir Kültür Vakfı tarafından yaptırılıp, üniversiteye bağışlanmıştır (Kızılkoyun \& Çağlar, 2012). İlk depremden yaklaşık beş ay sonra, Mart 2012'de üniversitenin geri kalanı da eğitime başlamış ve yoğunlaştırılmış eğitimle, ara verilen zaman telafi edilmeye çalışılmıştır (Özyıldıran, 2017-a; Özyıldıran, 2017-b; Özyıldıran, 2018) (Şekil 5). 


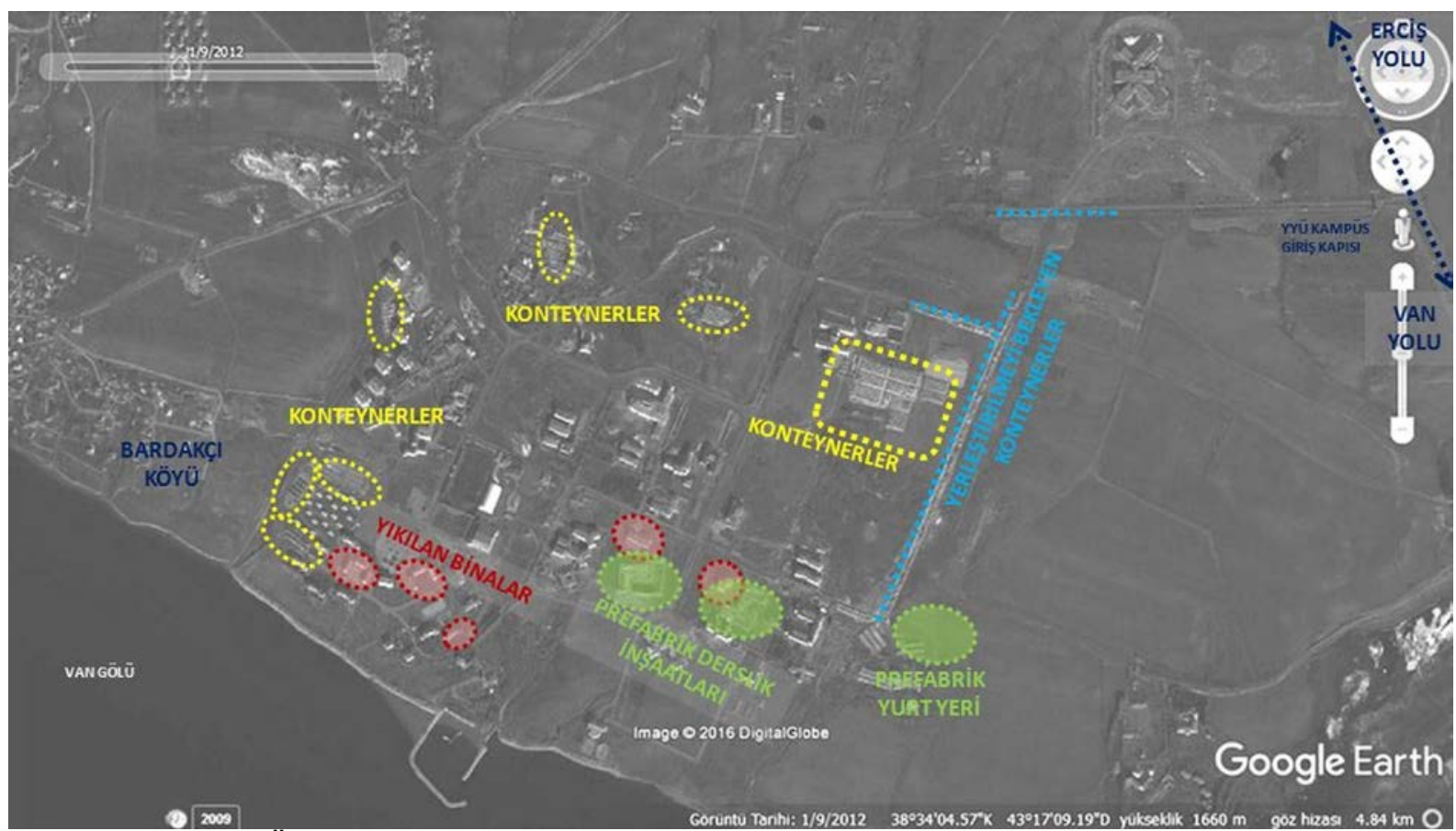

Şekil 5. Van YYÜ kampüsü konteynerler ve prefabrikler dönemi (kaynak: 09.01.2012 tarihli googleearth uygu görüntüsü üzerine yazar tarafından işaretlenmiştir)

Prefabrik dersliklere ilave olarak, kampüste konaklama için de 60 odalı 360 öğrenci kapasiteli bir prefabrik yurt Mart 2012'de açılmıştır. ODTÜ Eymir Vakfı da, kampüste bir adet 48 odalı prefabrik öğrenci yurdunu inşa edip, Kasım 2012'de tamamlayarak üniversiteye bağışlamıştır (Eymir Kültür Vakfı, 2020). Akademik ve idari personel için ise, tekil veya bitişik nizam olmak üzere, kampüste çeşitli tiplerde prefabrik lojmanlar inşa edilmiştir. Böylece, kampüste konteynerli bir dönemden sonra, prefabriklerle sürdürülen bir dönem olmuştur (Şekil 6). Prefabrik yapılar ile, içinde su ve ısıtma tesisatı olan, konteynerlere göre daha kalıcı yapılara geçilmiştir. Mevcut yapıların güçlendirilmesine kadar geçen sürede, üniversitenin eğitim ve idari hizmetleri konteynerler ve prefabrikler ile sürdürülmüştür. Bu süreçte, şehir merkezindeki çeşitli kamu kurumları da, konteyner ve prefabrik lojmanlar için üniversite kampüsünü kullanmıştır (Özyıldıran, 2017-b).
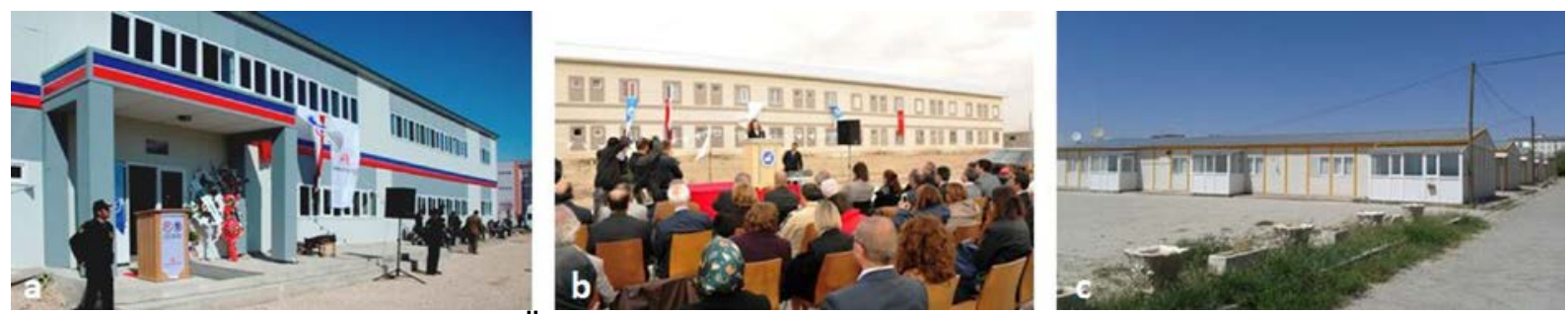

Şekil 6. Van YYÜ kampüsündeki prefabrik yapılardan örnekler:

a) ODTÜ Eymir Kültür Vakfı prefabrik derslik açılışı, 24.03.2012 (kaynak: odtuvanda.org/fotograflar.asp), b) ODTÜ Eymir Kültür Vakfı prefabrik yurt açılışı,

09.11.2012 (kaynak: http://www.vansiyaseti.com/van/yyude-195-kisilik-yurt-torenle-acildih5098.html), c) Prefabrik lojmanlardan örnekler (kaynak: Özyıldıran, 15.07.2016).

Günümüzde, kampüsteki deprem konteynerleri tamamen kaldırılmış olsa da, prefabrik derslikler, yurtlar ve lojmanlar hala kullanılmaya devam etmektedir. Dolayısıyla, afet yönetim döngüsü içerisinde, "iyileştirme aşaması" faaliyetleri olarak değerlendirilebilecek prefabrik yapılaşma, bir sonraki aşama olan "yapılanma aşaması" faaliyetlerinin başlangıcı olarak da değerlendirilebilmektedir. 


\section{4. Üniversitede Onarım ve Güçlendirme}

Afet yönetim döngüsünün iyileştirmeden sonraki aşamaları, "yapılanma", "korunma" ve "zarar azaltma" aşamalarıdır. "Zarar azaltma" aşamasını, modern afet yönetiminin kalbi olarak nitelendiren Kadıoğlu (2008), bu aşamayı "uzun dönemde tehlikeli durum ve bunların etkileri nedeni ile oluşabilecek can ve mal kaybı zararlarını azaltma veya ortadan kaldırmayı amaçlayan, sürekliliği olan aktivite ve önlemler" olarak tanımlamıştır. Bu aşamada, kampüste ilk yapılması gereken, en önemli faaliyetler, hasarlı yapıların tespiti, bu hasarlı yapılar arasından ağır hasarlıların yıkılması, orta hasarlıların güçlendirilmesi ve hafif hasarlıların onarılmasıdır.

Kampüsteki lojmanlar, fakülteler, bölümler, ilköğretim okulu, anaokulu, idari binalar, cami, araştırma hastanesi, mediko sosyal merkezi, yeni hayvan hastanesi, süt fabrikası, 2500 kişilik spor salonunun deprem tahkiki ve takviye projelerinin hazırlanması işi, "Van Yüzüncü Yıl Üniversitesi Kampüs Binalarının Deprem Performansının Tespiti ve Güçlendirilmesi projesi" kapsamında, 2012-2013 tarihli sözleşme ile Prota Mühendislik firmasına yaptırılmıştır (Prota Mühendislik, 2020). Firma, Van YYÜ kampüsündeki yaklaşık 214.000 m2'lik alanda bulunan yapıların, güçlendirme uygulanması gerektiği tespit edilenlerin güçlendirme projeleri, ihale dokümanlarının hazırlanması ve inşaat kontrollüğü hizmetlerini gerçekleştirdiğini, web sayfasında belirtmektedir (Prota Mühendislik, 2020).

\section{5. Üniversitede Yeni Planlamalar, Yeni Yapılar}

Üniversitenin prefabrik yapılar döneminin anlatıldığı önceki başlıkta, "iyileştirme" aşamasında kampüse yerleştirilen konteynerler ve yapımına başlanan prefabrik yapı inşaatları, Van YYÜ kampüsünün 9 Ocak 2012 tarihli uydu görüntüsü üzerinde işaretlenerek gösterilmişti (Şekil 5). Aşağıdaki Şekil 7'de ise, kampüsün aynı açıdan 22 Ağustos 2016 tarihli uydu görüntüsü yer almaktadır. Bu iki şekil karşılaştırılarak, kampüste yıkımı gerçekleşen binalar tespit edilmiş ve Şekil 5 üzerine işaretlenmiştir. İki şekil daha detaylı karşıllaştırıldığında ise, kampüste, "korunma" ve "zarar azaltma" aşamalarından sonra, "gelişme aşaması" olarak tanımlanabilecek, yeni planlama kararları ve yeni yapılaşmalar olduğu görülmektedir. Şekil 7'deki uydu görüntüsü üzerine eklenen yazı ve işaretlerle, bu farklııklara dikkat çekilmeye çalışılmıştır. 


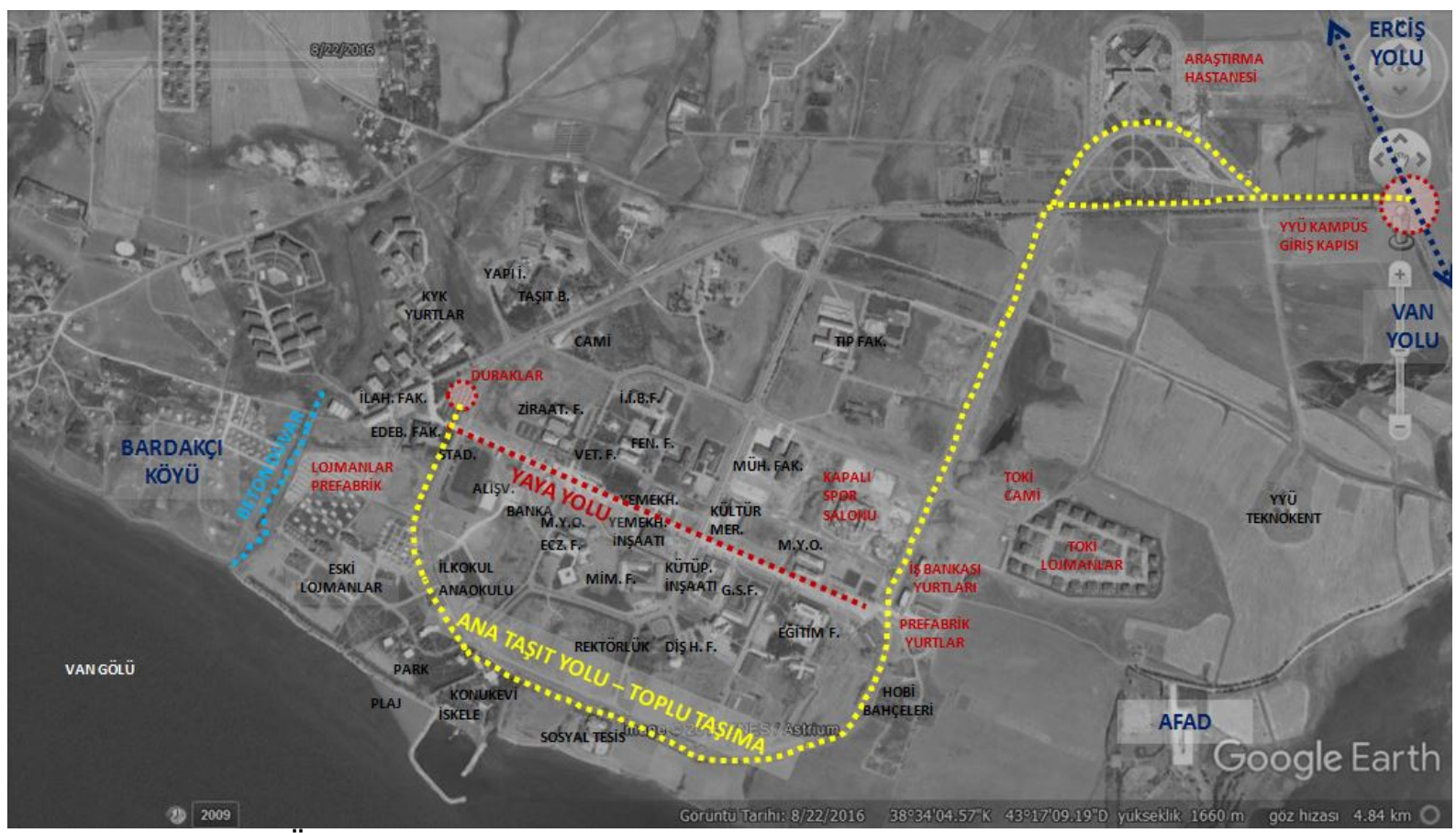

Şekil 7. Van YYÜ kampüsü yeni planlama ve yeni yapılaşma (kaynak: 22.08.2022 tarihli googleearth uygu görüntüsü üzerine yazar tarafından işaretlenmiştir)

İlk etapta, kampüste yıkılan yapılar yerine aynı fonksiyonları karşılayacak yeni yapılara intiyaç duyulmuştur. Bu kapsamda yurtlar ve lojmanlar öncelik kazanmıştır. Bazı yeni yapılar üniversite imkanları ile yapılmıştır, bazıları da dışarıdan destek alınarak yapılmıştır. Şekil 8'deki görülen, yeni lojmanlar ve camisi, TOKi tarafından, iki yurt binası da İş Bankası'nın bağışı olarak yapılmıştır. Bu yeni yurt ve lojman binalarının yeri için, kampüste deprem sonrası prefabrik yurtların yapıldığı bölgedeki boş alan seçilmiştir (Özyıldıran, 2017-b).
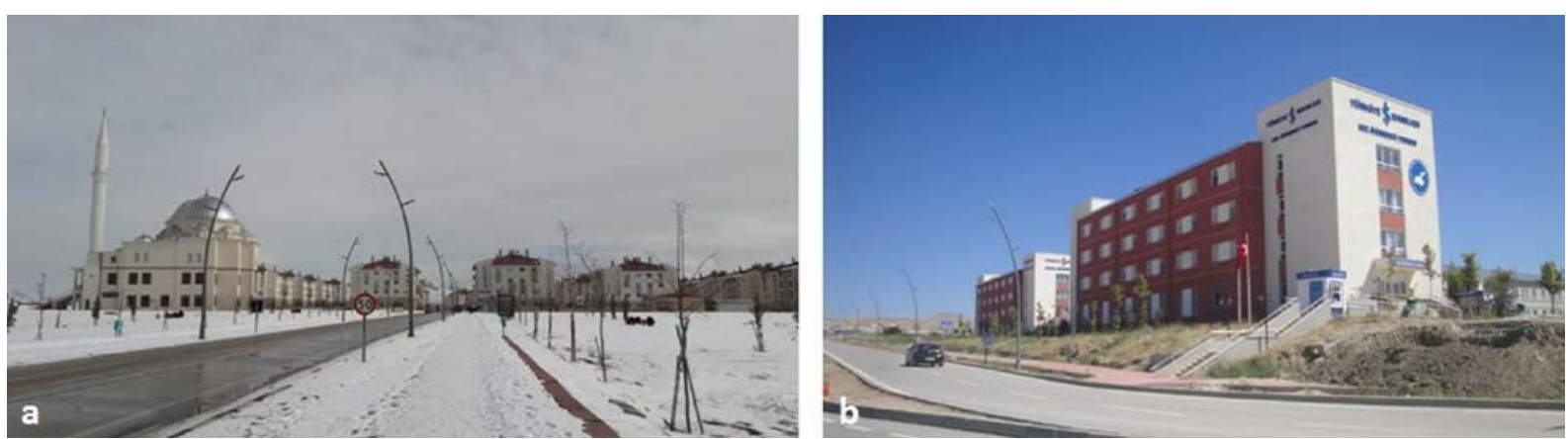

Şekil 8. Van YYÜ kampüsü deprem sonrası yeni yapılaşma a) TOKİ lojmanları (kaynak: Özyıldıran, 31.01.2017), b) İş Bankası öğrenci yurtları (kaynak: Özyıldıran, 19.09.2015).

Van YYÜ kampüsünün gelişimi için mevcut bir kampüs master planı olmadığı söylenmektedir, geçmişte hazırlanmış bir plan vardıysa da ulaşılamamıştır (Özyıldıran, 2017-b). Aslında, kampüsün mevcut yapılarının bir kısmının yıkıldığı ve yeni yapıların yapılmaya başlandığı bu afet sonrası dönem, 1982 yılında kurulmuş üniversitenin, zaman içinde yeni fakülteler ile büyümüş mevcut halini ve gelecekteki büyüme potansiyelini dikkate alan, yeni bir kampüs master planı yapılması ve kampüsün bu doğrultuda geliştirilmesi için önemli bir fırsat ortaya çıkarmıştır. Ancak afet sonrası dönemde, kriz anının problemlerini öncelilerine göre ve hızla çözmeye odaklanıımıştır. Yeni yapılaşma döneminin plan ve proje temininde, ekonomi ve hıza öncelik verilmiştir. Nitelikli bir kampüs mimarisi elde etmek için önemli bir unsur olan ve geçmişte Atatürk Üniversitesi, ODTÜ, Mersin Üniversitesi gibi bir 
çok üniversite için uygulanan, proje yarışması ile kampüs master planının ve yapı projelerinin elde edilmesi için önemli bir fırsat kaçırılmıştır.

Afet sonrası dönemde, kente ve üniversiteye yardımda bulunmak için, ODTÜ ve ITÜ gibi kurumların, Van YYÜ ile kurduğu yakın diyalog ve fikir alışverişleri sırasında, kampüsün geleceğine dair iki önemli planlama kararı ortaya çıkmıştır: 1) kampüs içindeki eğitim yapılarını çevreleyen ve içine toplu taşıma trafiğini almayan "ana taşıt yolu" ve 2) ana taşıt yolu ile çevrelenmiş bu alanın ortasından, göle paralel olarak geçen "yaya yolu (alle)" (Şekil 7). Şekil 5 ile karşılaştırıldığında görüldüğü gibi, ana taşıt yolu kararı; 1) birbirinden kopuk duran fakülte binalarının kampüs içindeki konumlarını, bir ana bölge içinde toplayarak daha tanımlı hale getirmiş, 2) lojman, ilkokul gibi ikincil servis fonksiyonu olan yapıları bu bölgenin dışında tanımlamış, 3) toplu taşıma trafiğini netleştirmiş, 4) fakülte binaları arasına araç trafiği girişini azaltmış, 5) birbiriyle yakın fonksiyonları olan, Konukevi ve Sosyal Tesisler gibi sahil birimlerini birbirine bağlamıştır. Aynı şekil üzeriden, yaya yolu (alle) kararı ile ilgili gözlem yapıldığında ise; 1) öncelikle ana bölge içinde fakülteler arası yürüyüş mesafesini eşitlemeye çalışan bir ana yaya omurgası oluşturulduğu, 2) deprem sonrası kampüsün doğusundaki boş alana yapılan yurtlar ve lojmalar ile ortaya çıkan ikinci konaklama bölgesini, depremden önce batıda konumlanmış olan ilk konaklama bölgesi ile bağladığı 3) konaklama birimleri ve fakültelerin birbiri arasında, yaklaşık eşit mesafede yaya erişilebilirliği sağlandığı, 4) kampüsün mevcut potansiyelini pekiştiren, yaya odaklı ve engelsiz kampüs olması yolunda önemli bir adım atıldığı görülmektedir.

Afet sonrası "gelişme aşaması", sadece depremde yıkılan binaların yerine yenilerinin yapıldığı değil, yeni ihtiyaçlara yönelik yeni binaların da yapımına başlandığı bir süreç olmuştur. Bu yapılara, yeni Kapalı Spor Salonu binası ve Araştırma Hastanesi çevresine yapılan yeni tesisler örnek olarak gösterilebilir. Van YYÜ, hızla büyümekte olan bir üniversite olduğu için, Turizm Fakültesi ve Uygulama Oteli, Mimarlık ve Tasarım Fakültesi, Güzel Sanatlar Fakültesi, Müzik ve Sahne Sanatları Fakültesi binaları gibi üniversitenin yeni kurulan birimler için, bundan sonraki süreçte de kampüste yeni yapılara ihtiyaç devam etmektedir (Özyıldıran 2017-a; Özyıldıran, 2018).

\subsection{Gelecek Olası Afetler İçin Hazırlanma Dönemi}

Afetlerin belli periyotlar ile tekrar etmesi nedeniyle, afet yönetim döngüsünün son aşaması, yeniden benzer bir afetin yaşanmasına karşılık "hazırlık" aşamasıdır. Bu aşamanın ana hedefi "tehlikenin insanlar için olumsuz etkiler doğurabilecek sonuçlarına karşı önlemler alarak, zamanında, en uygun şekilde ve en etkili organizasyon ve yöntemler ile müdahale edebilmeye hazırlanmaktır" (Kadıoğlu, 2008). Bu aşamada, üniversitenin afet acil durum planının hazırlanması, bununla ilgili bilgilendirmeler ve tatbikatlar yapılması, geçmiş afet deneyiminin hatırlatılıp, yeni fikirler üretilmesi önemlidir.

Van YYÜ'de, başta 2011 depremlerinin yıl dönümü olan 23 Ekim ve 9 Kasım tarihlerinde ve 1-7 Mart tarihlerindeki Ulusal Deprem Haftasında olmak üzere, afetler ve depremler üzerine seminer, panel vb. etkinlikler ara ara düzenlenmektedir. Şuanda üniversite'de okumakta olan lisans öğrencileri, 2011 Van depremleri sırasında üniversitede olmayan öğrencilerdir. Öğrencilerin büyük bir kısmı bu depremleri yaşayarak gelmiş olsa da, her sene yaş itibariyle bu süreci daha az hatırlayan bir öğrenci grubu gelmektedir. Bu nedenle, öğrencilere yönelik yapılan bu tip etkinlikler, unutulmadan, yaşanmış tecrübeden öğrencilerin istifade etmesini sağlayacaktır. Şekil 9'da, 2019 yılındaki, 23 Ekim 2011 depreminin son yıl dönümünde, kampüste yapılan etkinliğe katılan Van YYÜ Mimarlık 3.sınıf öğrencilerini göstermektedir. Mimari Tasarım dersi kapsamında etkinliklere katılan öğrenciler, AFAD, Kızılay ve Van Büyükşehir Belediyesi standlarından ve sergilerinden, geçmiş Van depremleri ile ilgili bilgi 
almış ve deprem simülasyon tırında, deprem tatbikatı yapmıştır. Tatbikat sırasında, sekizer kişilik gruplar halinde model sınıf içine alınan öğrenciler, Van depremi şiddetinde ve süresinde sarsıntıyı yaşamış, AFAD uzmanları eşliğinde deprem anında ve hemen sonrasında neler yapılması gerektiğini öğrenmişler ve uygulamışlardır. Bu tatbikat ile, daha önce deprem tecrübesi olmayan öğrenciler, depremi tecrübe etmiş, 2011 Van depremlerini yaşamış olan öğrenciler ise, tatbikatta öğrendikleri üzerinden, gerçek deprem anında yaptıkları doğruları ve yanlışları, arkadaşları ve AFAD ekipleri ile paylaşmış ve sorular sormuşlardır.
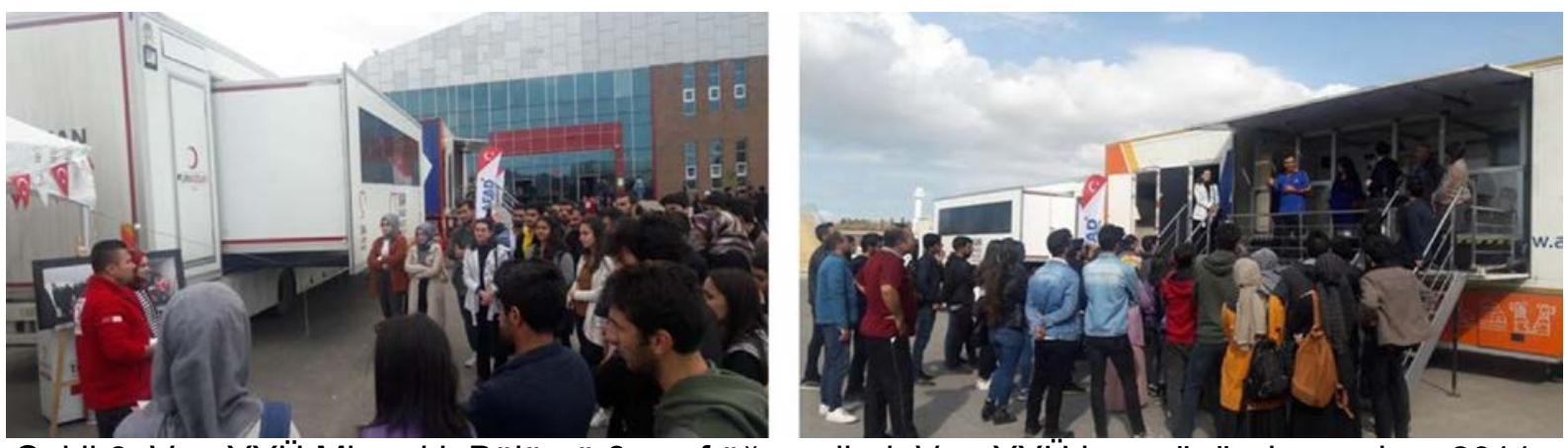

Şekil 9. Van YYÜ Mimarlık Bölümü 3.sınıf öğrencileri, Van YYÜ kampüsünde yapılan, 2011 Van depremleri yıldönümü etkinliklerinde (kaynak: Özyıldıran, 22.10.2019).

2011 Van depremlerinden sonra, kentte ve kampüste, deprem enkazlarının hızla kaldırılmış olması ve olumsuz kötü görüntünün hızla uzaklaştııılmış olması olumlu bir gelişmedir. Kenti yeni gören birinin, kentin yakın tarihte deprem yaşamış olduğunu anlaması neredeyse mümkün değildir. Ancak afet sonrası, yaşananlardan ders çıkarılabilmesi ve yine beklenmedik bir zamanda benzer bir afetle karşılaşılabileceğinin akılda tutulması, "hazırlıklı" olunması için önemlidir. Bu nedenle, kampüste bu dönemi hatırlatacak şeyler de gereklidir. Bu kapsamda, 2011 depremlerinde hayatını kaybeden Van YYÜ'nün Ayşe ve Mahire isimli iki öğrencisinin isimleri, "Ayşe Mahire Yurdu" adıyla prefabrik yurt binasında yaşatılmaktadır. 2011 'deki ilk depremden sonra yardım için Japonya'dan gelen, ancak ikinci depremde yıkılan otelde Van'da hayatını kaybeden Japon Doktor Atsushi Miyazaki'nin adı da, Van YYÜ Diş Hekimliği Fakültesi "Dr. Miyazaki Dis Ağız ve Diş Sağlığı Tedavi Merkezi" ile hatırlanmaktadır. ODTÜ Eymir Vakfı'nın yaptırdığı prefabrik derslik önündeki avludaki, göz yaşı formunda havuzun da, depremi hatırlatmak üzere tasarlandığı söylenmektedir. Deprem sonrası prefabrik bloklar, günümüzde hala önemli intiyaca cevap verdiği için kullanılmaktadır. Kampüsün daha nitelikli mimariye kavuşabilmesi için, en kısa zamanda bu yapılardan kalıcı yapılara geçilmesi ve vaktiyle plansız yerleşmiş olan prefabrik yapıların kaldırılması önemlidir. Ancak göz yaşı havuzunun bulunduğu avlu etrafında, düzenli yerleşmiş olan üç adet derslik bloğunun, kampüsün deprem dönemini hatırlatması ve zaman zaman o döneme ile ilgili etkinliklerde kullanılması için korunması gerekir. Ayrıca kampüsün yaya yolu, yemekhane, kütüphane gibi ortak kullanılan alanlarında, deprem dönemini hatılatacak nitelikli sanat eserleri yerleştirilmesi de, kampüs mimarisini bozmadan, deprem döneminin anısını hafızalarda taze tutmak için önemlidir.

\section{SONUÇ}

Bu çalışma kapsamında, yakın tarihte yaşanan 2011 Van depremleri üzerinden, Van YYÜ kampüsünde yaşananlar, modern afet yönetimi literatürüne dayanarak, mimarlık disiplini içinde incelenmeye çalışılmıştır. Önemli bir tecrübe olmasına rağmen, bu konuda yeterince yazılı kaynağa ulaşılamamış; söyleşilere, fotoğraflara ve yerinde gözlemlere dayanarak, afet yönetim süreci analiz edilmeye çalışılmıştır. Afet yönetiminde, bir üniversite kampüsünün, kent geneline göre daha farkı intiyaçları, daha farklı öncelikleri ve imkanları olduğu 
görülmüştür. Arama kurtarma çalışmalarından sonra, kentteki uygulamada, evlerine giremeyen afetzedeler için çadır ve yemek temini öncelik kazanırken; üniversite kampüsünde, öğrencilerin yakınları ile haberleşmelerinin sağlanması ve kısa süre de memleketlerine ulaştırılması birinci öncelik olmuştur. İkinci öncelik ise, öğrenci ve personelin geçici barınma ve çalışma mekanlarının bir an önce temin edilerek, en az zaman kaybıyla eğitime dönülebilmesi olmuştur.

Afet sonrasında, hem kent için, hem de üniversite kampüsü için yeni planlama ve tasarım fırsatları ortaya çıktığı görülmüştür. Ancak afetin hemen sonrasındaki tasarım ve uygulamalarda, ekonomi ve sürat ön plana çıkmaktadır. Bu nedenle, planlama ve tasarım konusunda, afet öncesinde, "zarar azaltma" aşamasına doğru kararlar almak önemlidir.

Üniversite, kentin afet yönetimine, bilimsel ve mesleki uzmanlık desteklerinin yanı sıra, kampüs imkanları ile de katılmıştır. Afet hemen sonrasında, kalabalık dokusu içerisinde, yıkılan yapılar, boş alanlara kurulan geçici çadır ve konteyner yerleşimleri, kent dışından desteğe gelenler $\mathrm{vb}$. ile kentin daha da kaotik hale geldiği tahmin edilebilmektedir. Bu noktada, kentin biraz dışında, seyrek ve düzgün yapılaşması ile üniversite kampüsü, afet yönetimi için güvenli bir mekan sunmuştur. Ayrıca, deprem sonrasında kente katkı koymak isteyen diğer üniversitelerin de, bu desteklerini Van YYÜ odağında gerçekleştirdiği görülmüştür. Van YYÜ'nün yaşadığı bu deprem tecrübesi, bütün bir kentin faaliyetlerini kesintiye uğratan 2011 Van depremleri gibi büyük afetlerde, kentlerin afet yönetiminde, kendi üniversitelerinin ve kampüslerinin önemli bir rol alabileceğini göstermiştir.

\section{KAYNAKLAR}

AFAD (2014-a). Açıklamalı Afet Terimleri Sözlüğü. Ankara: T.C. Başbakanlık Afet ve Acil Durum Yönetimi Başkanlığı.

AFAD (2014-b). Müdahale, lyileştirme ve Sosyoekonomik Açıdan 2011 Van Depremi. Ankara: T.C. Başbakanlık Afet ve Acil Durum Yönetimi Başkanlığı.

AFAD (2020). Resmi web sayfası. Erişim adresi: https://www.afad.gov.tr/ (son erişim tarihi: 27.04.2020).

Battal, P. (2016). Rektör, Açılış Konuşması. Van'da Deprem Farkındalığını Geliştirme Sempozyumu, 5 Mayıs 2016 (Yayımlanmamış sözlü sunum). Van: Van Yüzüncü Yıl Üniversitesi.

Boğaziçi Üniversitesi KRDAE (2020). Büyük Depremler. Boğaziçi Üniversitesi Kandilli Rasathanesi ve Deprem Araştırma Enstitüsü, Bölgesel Deprem ve Tsunami İzleme ve Değerlendirme Merkezi. Erişim adresi: http://www.koeri.boun.edu.tr/sismo/2/deprembilgileri/buyuk-depremler/ (son erişim tarihi: 27.04.2020).

Ergünay, O. (2007). Türkiye'nin Afet Profili. TMMOB Afet Sempozyumu, ss.1-14.

Eymir Kültür Vakfı. ODTÜ Van'da. Erişim adresi: http://www.odtuvanda.org/ (son erişim tarihi: 27.04.2020).

JICA (2004). Türkiye'de Doğal Afetler Konulu Ülke Strateji Raporu. Ankara: Japon Uluslararası İşbirliği Ajansı.

Kadıoğlu, M. (2008). Modern, Bütünleşik Afet Yönetimin Temel İlkeleri. Afet Zararlarını Azaltmanın Temel İlkeleri, ss.1-57. 
Kızılkoyun, F. \& Çağlar, M. (2012). Van Konteyner Üniversitesi. Hürriyet Gazetesi, 25.01.2012. Erişim adresi: https://www.hurriyet.com.tr/gundem/van-konteyner-universitesi19766862 (son erişim tarihi: 27.04.2020).

Özyıldıran, G. (2018). Doğu Anadolu Bölgesinin İlk Mimarlık Okulu: Van Yüzüncü Yıl Üniversitesi Mimarlık Bölümü. International Culture, Art and Society Symposium, 18-21 Ekim 2018. Van: Van YYÜ Güzel Sanatlar Fakültesi, ss.666-675.

Özyıldıran, G. (2017-a). Moving Classrooms from a Disaster Relief Structure to a Permanent Faculty Building: Perceptions of Students of Architecture in Van. ARCHTHEO'17 XI. Theory and History of Architecture Conference, 3-4 Kasım 2017. İstanbul: DAKAM, ss.133-139.

Özyıldıran, G. (2017-b). 2011 Van Depremi Sonrasında Yüzüncü Yıl Üniversitesi Kampüsü'ndeki Değişimler. Türkiye'nin Afet Risk Yönetimi On Dokuzuncu Yuvarlak Masa Toplantısı. (Yayımlanmamış sözlü sunum). Ankara: Orta Doğu Teknik Üniversitesi, 24 Mart 2017.

Özyıldıran, G. (2013). Disasters and Buildings: The Effects of Turkish Disaster Regulations on Architectural Design. Saarbrucken: LAP Lambert Academic Publishing.

Özyıldıran, G. \& İmamoğlu, V. (2010). Afet Yönetmeliğinin Mimari Tasarım Açısından İncelenmesi. Yapı Dünyası Dergisi, no.172, s.17-22.

Sezen, L. (2008). Anılarıyla Bir Üniversitenin Kuruluş Sancıları. Ankara: Belen Ofset. 